\title{
PERFORMANCE EVALUATION OF DIESEL ENGINE USING BIODIESEL FUEL DERIVED FROM WASTE COOKING REFINED SOYABEAN OIL
}

\author{
SHIV KUMAR SHARMA ${ }^{1}$, D.D. SHUKLA ${ }^{2}$, \\ KAMAL KISHORE KHATRI ${ }^{3}$ \& NITESH SINGH RAJPUT ${ }^{4}$ \\ ${ }^{1,4}$ Research Scholar, Amity University Jaipur, India \\ ${ }^{2}$ Professor, Amity University Jaipur, India \\ ${ }^{3}$ Associate Professor, LNMIIT Jaipur, India
}

\begin{abstract}
Brazil is using bio-diesel as an alternate fuel to run cars. Rapid growth of bio-fuels all around the world is mainly due to energy crisis and ecological concerns, and in this dynamic market mechanisms, lot of efforts are being made to facilitate the growth of bio-fuels. In India, the main Goal of the Biofuel Policy is to make sure that, a bare minimum level of bio-fuels turns out to be readily accessible in the marketplace, to meet up the requirement at any given time. A pinpointing objective of $20 \%$ blending of bio-fuels, by 2017 was to be achieved, but still we are far behind. Even though raw vegetable oils can also be used in compression ignition engines, however, their high viscosities, poor flow properties in cold and low volatilities have made them unsuitable. Consequently, we need to investigate various other derivatives. In this research, Biodiesel was prepared by the process of trans-esterification, from waste cooking refined soyabean oil. Thereafter, an experimental investigation was carried out on a 4 - stroke Compression ignition engine, with single cylinder which is fueled with blends of Biodiesel and petro diesel. 6 blends of biodiesel were taken for investigating performance characteristics of engine, under different conditions of load. Blend B20 of biodiesel was found most suitable among all blends of biodiesel and petro diesel
\end{abstract}

Keywords: Biodiesel, Performance, Diesel Engine \& Waste Cooking Oil

Received: Aug 02, 2017; Accepted: Aug 19, 2017; Published: Aug 30, 2017; Paper Id.: IJMPERDOCT201711

\section{INTRODUCTION}

In India, it is a common practice to use waste cooking oil repeatedly, for frying purpose in domestic use as well as commercial use. This waste cooking oil may be carcinogenic. Scientists have found that, repeated use of waste cooking oil is dangerous for health, because it releases toxic aldehydes and alylbenzenes $(1,2)$, which may be linked to serious illnesses like cardiac problems, dementia and cancer. Keeping the large population of India in mind, dumping of waste cooking oil may enforce severe ecological issues. Also, it is unhealthy for cattle feed. Hence, best possible way to use waste cooking oil is that, it should be converted into bio-diesel by the process of trans-esterification, if the FFA is less than $2.5 \%$, otherwise by a 3 step process of saponification, acidification and trans-esterification.

Basically, in the process of Trans-esterification, triglycerides present in waste cooking oils are converted into a mixture of esters (mono alkyl), with the help of an alcohol and catalyst is used to accelerate reaction toward the right hand side and to obtain better yields of the biodiesel. Methyl or ethyl esters so obtained, are having very much comparable properties, to those of petro based diesel fuels. The foremost byproduct of the process of trans- 
esterification is glycerol. The most frequently used alcohol, for the manufacture of biodiesel is methanol $\left(\mathrm{CH}_{3} \mathrm{OH}\right)$ for the reason that, it's cheaper in price and comparatively gives higher rates of conversion. Other alcohols like plant based alcohols ethanol, propanol, butanol and isopropanol can also be used. Trans-esterification is a reversible reaction. In the presence of excess alcohol, the rate of forward reaction is higher than the rate of backward reaction. Many catalysts like acid, alkali and solids can be used in this process; however, process trans-esterification can be completed at a faster rate using an alkali catalyst like $\mathrm{NaOH}$ and $\mathrm{KOH}$.

TRANS-ESTERIFICATION

$$
\begin{aligned}
& \mathrm{CH}_{2}-\mathrm{OCOCR}_{1} \\
& \mathrm{CH}_{2}-\mathrm{OCOR}_{3} \\
& \begin{array}{l}
\text { Waste Cooking } \\
\text { Oil (Triglyceride) }
\end{array}
\end{aligned}
$$

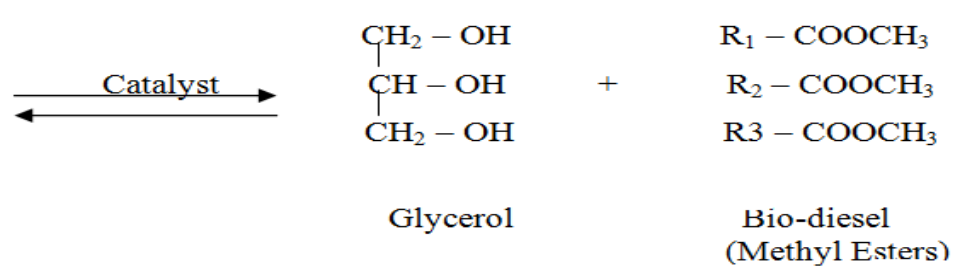

\section{METHODOLOGY}

First, used cooking oil was collected from the residue oil of a marriage function in Alwar and local restaurant fuel zap. Since, it was contaminated and blackish in colour, paper filter (pore size 11 micrometer) was used to remove debris and food particles in it, for a period of 6 hours. It was filtered twice using paper filter. Then free fatty acid (FFA) test was conducted in Jagdamba lab Jaipur. FFA was found to be $0.2543 \%$. If FFA is less than $2.5 \%$, then it is good for conversion into biodiesel. 5 litre of waste cooking oil was measured and it was stirred and heated up to a temperature of $57{ }^{\circ} \mathrm{C}$. Simultaneously, in another beaker anhydrous methanol 1.4 litre was mixed with $900 \mathrm{ml}$ of Sodium hydroxide (NaOH). Second beaker was heated because of exothermic reaction and methoxide was formed. It was poured slowly in heated cooking oil. Oil was stirred gently. Then it was allowed to cool and left for 15 hours. This is the process of transesterification. Glycerol being heavier was collected (1.5 litre) at bottom and it was separated. We heated approx 1 litre of water separately, up to a temperature of $75-80^{\circ} \mathrm{C}$ and this hot water was added to the left out solution. Subsequently, it is shaken strongly and after that allowed to settle for about 6 hours. This method is known as water washing, it is used to get rid of unexploited catalyst and other contaminants. Water washing was repeated two times for improved outcomes. This method is repeated two to three times and at each point of time, a small fraction of biodiesel is checked with the help of litmus paper into the solution. If the colour of the litmus paper changes it means that, more water washing is required as shown in figure.

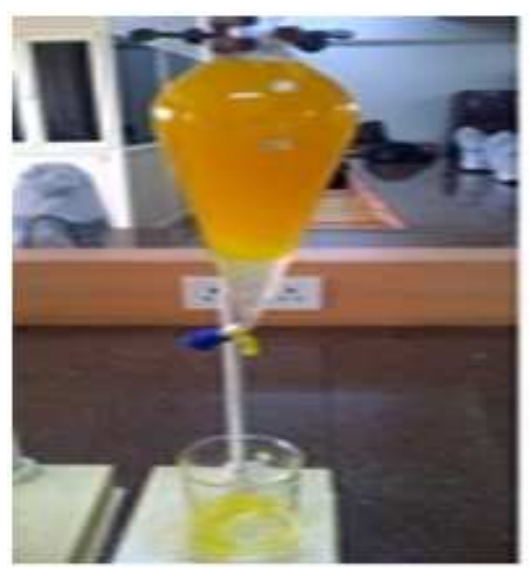

Figure 1: Water Washing 
Following this testing, if the colour of the litmus doesn't change, it means that Bio-diesel so prepared is now ready for further use.

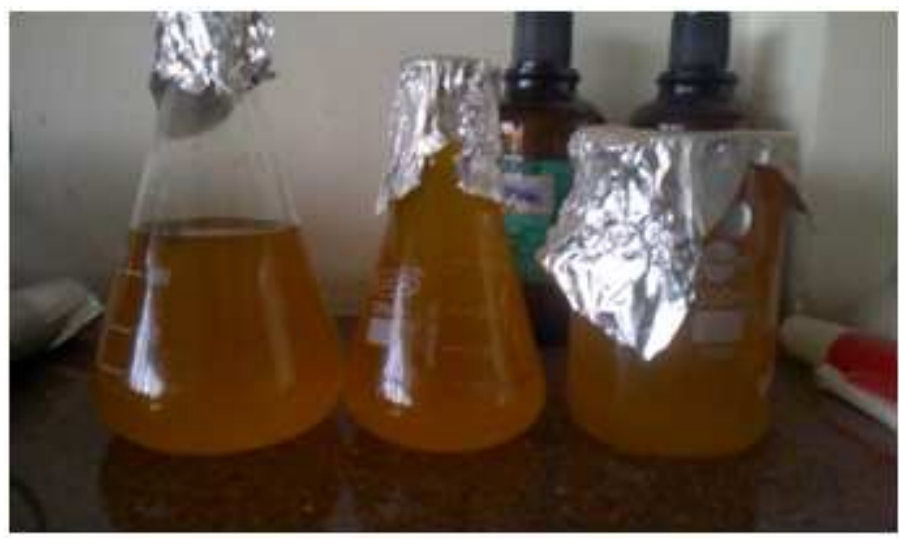

Figure 2: Bio-Diesel

\section{FUEL PROPERTIES}

The fuel properties are given in Table 1, for Biodiesel; Petro based diesel and their blends from $10 \%$ to $60 \%$ by volume (B10, B20, B30, B40, B50, and B60). Higher order blends are not preferred due to increasing viscosities.

Table 1: Density and Heating Values of Blends (Sharma S.K. et al)

\begin{tabular}{|l|c|c|}
\hline Type of Blend & Density $\left(\mathbf{k g} / \mathbf{m}^{\mathbf{3}}\right)$ & Heating Value $\mathbf{( k J} / \mathbf{k g})$ \\
\hline B10s & 848.2 & 43970.4 \\
\hline B20 & 861.4 & 43142 \\
\hline B30 & 867.6 & 42310 \\
\hline B40 & 885.8 & 41485 \\
\hline B50 & 901.5 & 40650 \\
\hline B60 & 912.2 & 39825 \\
\hline
\end{tabular}

Various properties of Biodiesel which was produced in this investigation are listed in table -2 as shown below:

Table 2: Fuel Properties of Biodiesel (Sharma S.K. et al)

\begin{tabular}{|l|c|c|c|}
\hline \multicolumn{1}{|c|}{ Property } & Bio-Diesel & Petro-Diesel & Testing Method \\
\hline Density (at $\left.15^{\circ} \mathrm{C}\right) \mathrm{Kg} / \mathrm{m}^{3}$ & 967 & $820-845$ & IS 1448 Part - 1 \\
\hline Kinematic Viscosity Centi Stoke & 4.25 & 2.228 & IS 1448 Part - 1 \\
\hline Flash Point (Abel) in ${ }^{\circ} \mathrm{C}$ & $147^{\circ} \mathrm{C}$ & $52-96$ & IS 1448 Part - 1 \\
\hline Pour Point in ${ }^{\circ} \mathrm{C}$ & $5.2^{\circ} \mathrm{C}$ & $3^{\circ} \mathrm{C}$ & IS 1448 Part - 1 \\
\hline Heating Value $\mathrm{kJ} / \mathrm{Kg}$ & 36504 & 44800 & Bomb Calorimeter \\
\hline Cetane Index & 48.2 & 46 & D 4737 / ISO 4264 \\
\hline Content of Sulphur in PPM & 5.7 & 350 & ISO 8754/ P:83 \\
\hline
\end{tabular}

\section{EXPERIMENTAL TEST SETUP}

Tests of biodiesel were conducted on a four stroke single cylinder engine, water cooled, direct injection, Kirloskar AV1 5 BHP diesel engine at $1500 \mathrm{rpm}$. The Test rig consists of engine test bed, along with fuel supply system and various metering and measuring devices with the rig. A water brake dynamometer was mechanically coupled with the engine. Load variations were carried out, by using flow control of the dynamometer. Fuel supply was made by an external plastic container. Fuel was preheated manually by a gas burner. However, direct use of B100 in engine was not possible, due to 
high viscosity as it may cause excessive vibration. Digital tachometer was used to measure rpm of the engine. Lubricating oil temperature was measured by platinum-type thermocouple and exhaust manifold temperature was measured by laser gun thermometer. Operating condition of the engine is given in Table 3.

Table 3: Specifications of Test Rig (Sharma S.K. et al)

\begin{tabular}{|l|l|}
\hline Detail & Specification \\
\hline Type & Vertical CI Engine \\
\hline Number of Cylinder & Single Cylinder \\
\hline No. of Stroke & 4 \\
\hline Bore (mm) & 87.5 \\
\hline Stroke length (mm) & 110 \\
\hline Speed & 1500 RPM \\
\hline Cooling & Water cooled \\
\hline Compression Ration & $19: 1$ \\
\hline Starting Method & Hand Starting \\
\hline Lubricating Oil Used & SAE40 \\
\hline Rated Power & 5 BHP \\
\hline CC of engine & 600 \\
\hline
\end{tabular}

Engine was run at different 4 loads $(0 \mathrm{~kg}, 1 \mathrm{~kg}, 3 \mathrm{~kg}$ and $7 \mathrm{~kg})$, for each of the fuel blend; the engine load was controlled by dynamometer. For all 6 blends of different concentration, speed in rpm, Torque, Fuel Consumption, and Temperature of exhaust gas were measured. Then volumetric efficiency, Brake Power, Brake specific fuel consumption, and brake thermal efficiencies were calculated by means of the data generated in the trial.

\section{RESULTS AND DISCUSSIONS}

The effect of different blends of biodiesel with load was tested and the effects of these parameters are discussed here, in the following texts.

\section{Effect on Volumetric Efficiency}

Figure 3 Portrays Effect of Biodiesel Concentration on Volumetric Efficiency of the Engine

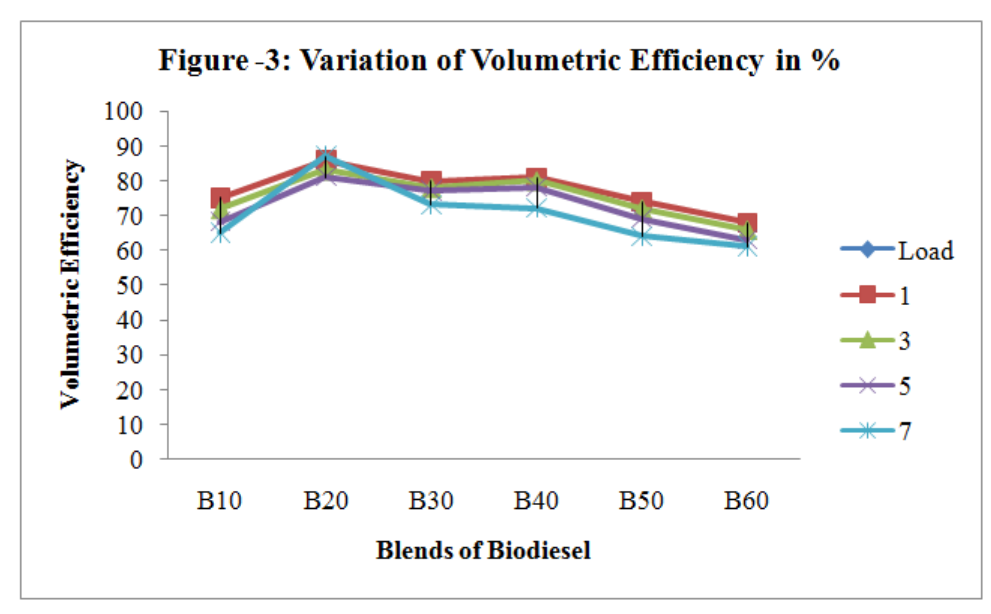

It is clear from the figure- 3 that, volumetric efficiency of all blends decrease with the load. This is because of the fact that, speed of engine is decreases with load. 


\section{Effect on BP (Brake Power)}

Figure 4, reflects the effect of load on the BP of CI Engine, for different blends of biodiesel. It is clear from the graph that, BP Requirement increase when load is increased. BP can be calculated easily by using formula:

B.P. $=\frac{2 \pi N T}{60}$, where $\mathrm{T}=$ Torque in $\mathrm{N}-\mathrm{m}, \mathrm{N}=$ Speed in $\mathrm{RPM}$

The BP for biodiesel is little bit higher than the petro diesel, for all conditions of load. At $7 \mathrm{~kg}$ load, the BP of biodiesel blend B30 was found maximum. It is possibly due to better combustion of biodiesel for B30 blend.

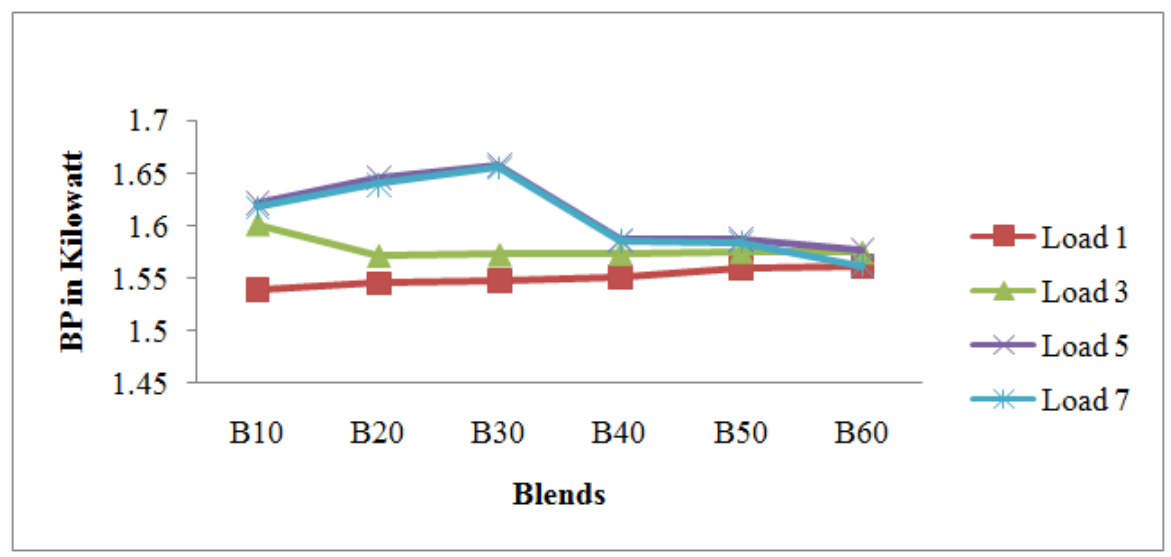

Figure 4

\section{Effect on Fuel Consumption}

Variations of fuel consumption with load are shown in the figure -5. It is evident that, fuel consumption is high for all blends at maximum loading. Even if engine runs freely without load, fuel consumption is not zero.

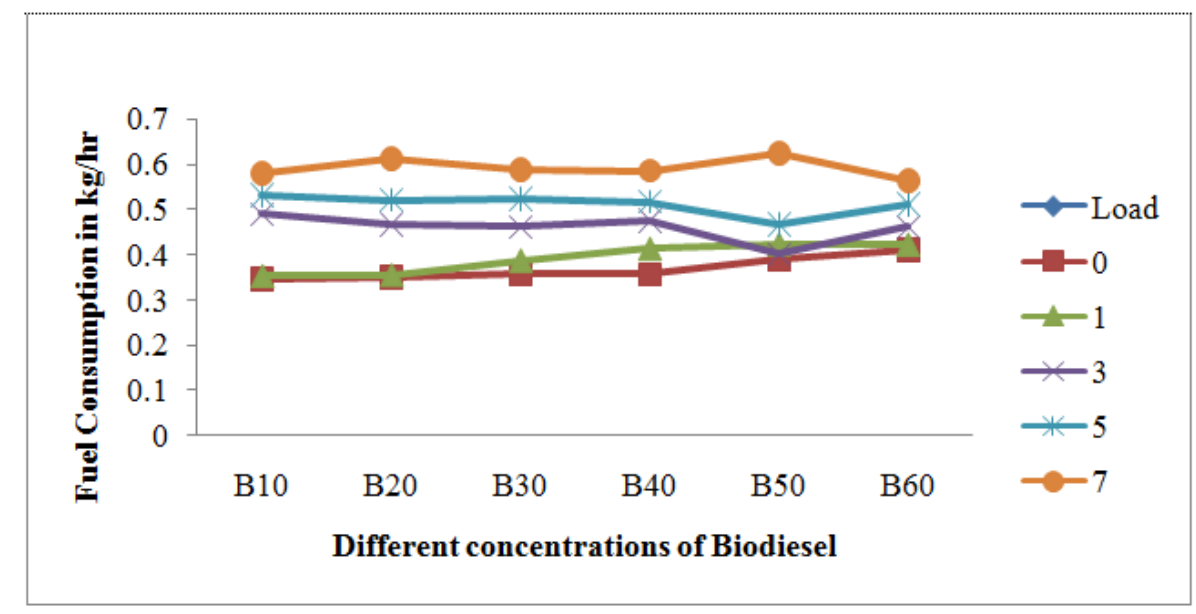

Figure 5

\section{Effect of Concentration on Mechanical Efficiency}

Mechanical efficiency of an engine is defined as the ratio of brake power and indicated power provided that, both are expressed in the same unit. Variations of mechanical efficiency for different blends are shown at different loads, in the figure- 6. Mechanical efficiency increases with increase in concentration of biodiesel and increase in load. Variations in mechanical efficiency with concentration are in a very narrow range. While maximum mechanical efficiency was just 
above $80 \%$.

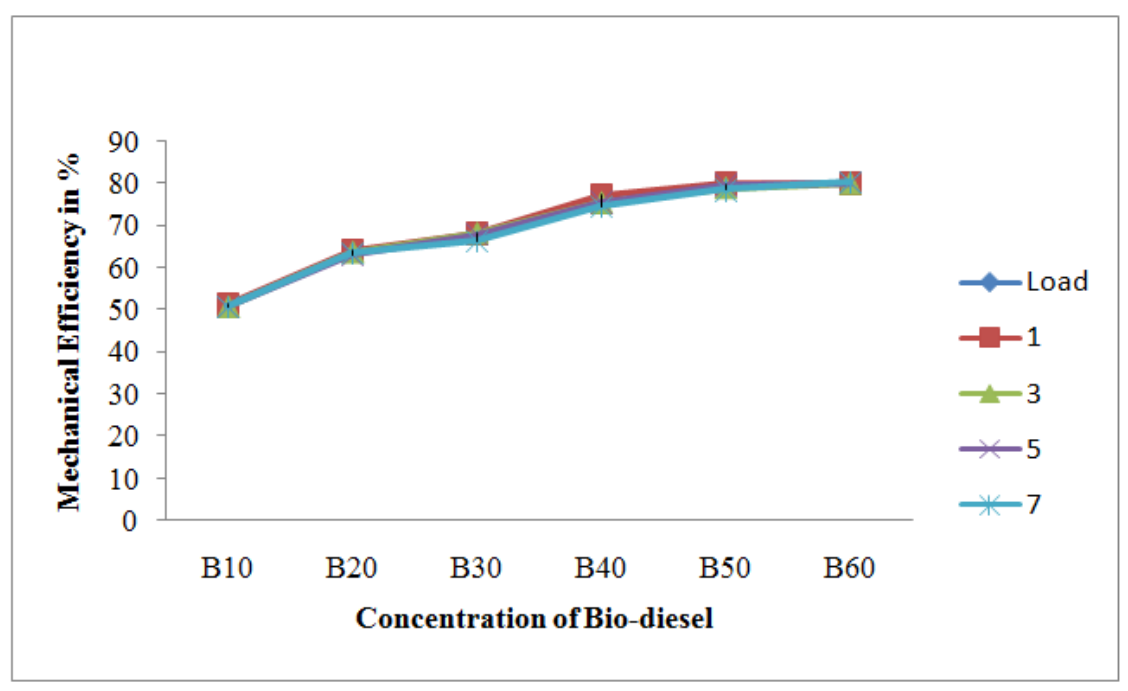

Figure 6

\section{Effect of Concentration on BSFC}

Brake Specific Fuel Consumption (BSFC), is the fuel consumption per unit time per unit brake power. It is a measure of the performance of the engine. Variations of BSFC with load are shown in figure -7 , for various concentrations.

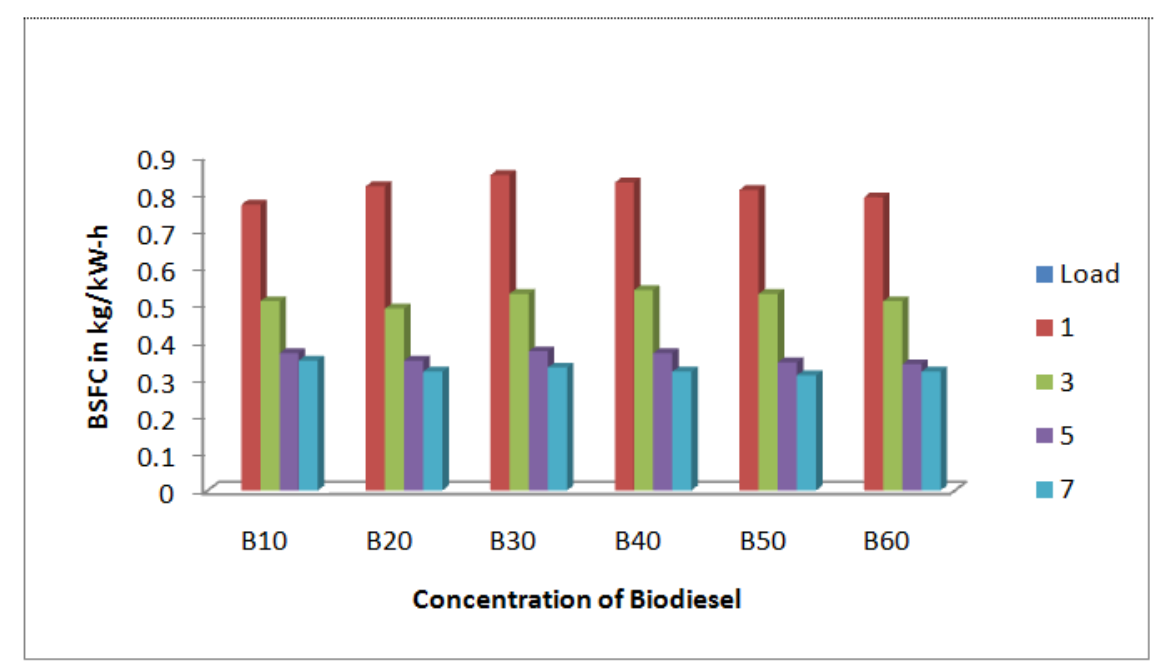

Figure 7

\section{CONCLUSIONS}

In this research paper, bio-diesel was prepared from waste cooking oil (refined soyabean oil), by the process of trans-esterification. Properties of biodiesel were very much closer to that of petro diesel. Various conclusions drawn from engine test are as follows:

- Bio-diesel should not be used in $100 \%$ form this is because of the fact that viscosity of bio-diesel is higher that of diesel and volatility of biodiesel is less than that of diesel.

- Performance of biodiesel for Different blends is different, therefore it is advisable to find best bend as per requirement for biodiesel produced from different source 
- Volumetric efficiency and BP are higher for B20 blend. Moreover, it is clear from different graphs that best results are obtained if concentration of biodiesel is within the range of $20 \%-30 \%$ by volume.

- By using Bio-diesel, we can solve problem of disposal of waste oil and further it can improve rural economy and its eco-friendly nature will have good results in terms of emission norms.

\section{REFERENCES}

1. Maria D. Guillen, Patricia S. Uriarte Aldehydes contained in edible oils of a very different nature after prolonged heating at frying temperature: Presence of toxic oxygenated $\alpha, \beta$ unsaturated aldehydes, Food Chemistry. 2012; 131(3) : 915-926

2. P. S. Uriarte, Maria D. Guillen Formation of toxic alkylbenzenes in edible oils submitted to frying temperature: Influence of oil composition in main components and heating time, Food Research International. 2010; 43(8): 2161-2170

3. Deepak Tanwar, Ajayta, Dilip Sharma, Y. P. Mathur, Production And Characterization Of Neem Oil Methyl Ester, International Journal of Engineering Research \& Technology (IJERT). 2013; 2 (5) : 1896 -1903

4. D. Rachel Evangelene Tulip and K.V. Radha, Production of biodiesel from mustard oil its performance and emission characterization on internal combustion engine, Advanced Engineering and Applied Sciences: An International Journal 2013; 3(3), $\boldsymbol{P P}: 37-42$

5. R. Sarala, M. Rajendran, S.R. Devdasan, Emission characteristics of mustard oil methyl ester (MOME)-diesel fuel blends on a C.I. engine, International Journal of Green Chemistry and Bioprocess. 2012; 2(1) : 6-10.

6. P. Sivakumar, K. Anbarasu, S. Renganathan, Bio-diesel production by alkali catalyzed transesterification of dairy waste scum Fuel. 2011; $90:$ 147-151.

7. Siva Kumar, D. Maheswar, K. Vijaya Kumar Reddy, Comparision of Diesel Engine Performance and Emissions from Neat and Transesterified Cotton Seed Oil, Jordan journal of mechanical and industrial engineering. 2009;3(3):190-197.

8. Gautam Kumar and Anoop Kumar, Engine Performance Characteristics of Diesel Engine Using Mahua Biodiesel as Fuel, International Journal of Current Engineering and Technology .2013;3(2): 424-427

9. K. Mu'azu, I. A. Mohammed-Dabo, S. M. Waziri, A. S. Ahmed, I. M. Bugaje and A. S. Ahmad Development of a mathematical model for the esterification of Jatropha curcas seed oil, Journal of Petroleum Technology and Alternative Fuels. 2013;4(3): 44-52

10. Seid Yimer, Omprakash Sahu, Optimization of Biodiesel Production from Waste Cooking Oil, Sustainable Energy. 2014; 2(3) $: 81-84$

11. Zheng, S., Kates, M., Dube, M.A., and McLean, D.D(2006)., "Acid-catalyzed production of biodiesel from waste frying oil" Biomass \& Bioenergy 30, 267. Ye-book.

12. Dennis Y.C. Leung *, Xuan Wu, M.K.H. Leung (2010), A review on biodiesel production using catalyzed transesterification, Applied Energy 87 PP :1083-1095

13. Chitra P, Venkatachalam P, Sampathrajan A. Optimisation of experimental conditions for biodiesel production from alkalicatalysed transesterification of Jatropha curcus oil. Energy Sustain Dev 2005;9(1), PP:3-8.

14. Balaji Mohan, Wenming Yang, Wenbin Yu, Kun Lin Tay, SiawKiang Chou (2015), Numerical investigation on the effects of injection rate shaping on combustion and emission characteristics of biodiesel fueled Cl engine, Appl. Energy I60 PP: 737745 .

15. M. Christopher and R. Sabarish(2014),, Emission Analysis of a Single Cylinder Di Engine Running on Biodiesel Blend as 
Fuel, Middle-East Journal of Scientific Research 20 (6) PP: 681-684,

16. Sudipta De 1, Rafael Luque, Upgrading of waste oils into transportation fuels using hydrotreating technologies. Biofuel Research Journal 4 (2014) PP: 107-109.

17. S.K. Sharma, Dr. D.D. Shukla, Dr. K.K. Khatri and Nitesh Singh Rajput, Comparative Analysis of Performance of C.I. Engine Fuelled with Different Blends of Biodiesel Derived from Waste Cooking Oils of Two Different Sources, International Journal of Mechanical Engineering and Technology, 8(6) 2017, PP: 714 -721 